\title{
Potential of Humicola phialophoroides biomass for zinc (II) removal from aqueous solution
}

\author{
Tinnapan Netpae* \\ Environmental Science Program, Faculty of Science and Technology, Nakhon Sawan Rajabhat University, Thailand \\ *Corresponding author, E-mail: tinnapan.n@nsru.ac.th
}

\begin{abstract}
The purpose of this research was to estimate the $\mathrm{Zn}^{2+}$ biosorption by biomass of Humicola phialophoroides fungus isolated from creek sediments in a zinc mine area in Thailand. The Langmuir isotherm model gave a better fit for the result data more than Freundlich, Temkin and Dubinin-Radushkevich isotherm models. $\mathrm{Zn}^{2+}$ removal ability in all H. phialophoroides biomass types as increasing $\mathrm{Zn}^{2+}$ concentration had the same pattern, but biomass pretreated by $\mathrm{NaOH}$ showed better $\mathrm{Zn}^{2+}$ removal ability than viable biomass, nonviable biomass, and $\mathrm{HNO}_{3}$ pretreated biomass. Maximum $\mathrm{Zn}^{2+}$ biosorption of biomass pretreated with $\mathrm{NaOH}$ took place at initial solution at $\mathrm{pH} 8$ after $150 \mathrm{~min}$. In addition, $\mathrm{Zn}^{2+}$ was well adsorped by $\mathrm{NaOH}$ pretreated biomass at temperature higher than $70{ }^{\circ} \mathrm{C}$, while desorption experiments indicated that the desorption efficiency with $0.1 \mathrm{M} \mathrm{HNO}_{3}$ solution reached $92.31 \%$.
\end{abstract}

Key words: biosorption, Humicola phialophoroides, pretreated biomass, $\mathrm{Zn}^{2+}$.

Abbreviations: ITS, internal transcribed spacer; PDA, potato dextrose agar; PDB, potato dextrose broth.

\section{Introduction}

Zinc is a widespread heavy metal ion in natural systems including water, air, sediment and soil. More than 13 million tons of zinc was produced in 2013 worldwide (U.S. Geological Survey 2014). Approximately $70 \%$ of zinc comes from mined ores and 30\% comes from recycled sources (Hosford 2013). Approximately $80 \%$ of zinc is used in galvanizing to protect steel from corrosion (The National Mining Association 2014). At background levels, it is an essential nutrient for human, animal and plant life. However, high concentrations of zinc can be harmful and can cause toxicity.

The commonly used procedures for removing metal ions from aqueous solutions include ion exchange, chemical precipitation, lime coagulation, reduction process, membrane technologies, and activated coal applied to remove these solutions of heavy metals, but these can be expensive and are often limited at high concentration (Zabochnicka-Świątek, Krzywonos 2014). At present, the bioremoval treatment process of metals has received increasing attention in term of biosorption, because of its many advantages such as the ability to treat large volumes of wastewater, rapid kinetics and high selectivity in the removal and recovery of specific heavy metals. Manystudies have reported that fungi biomass possesses high metal removal, intracellular uptake of the metal ions occur by the cells, the process involves metabolism using living cells, and the cell surface sorption allows interaction between toxic metal ions and functional groups such as carboxylate, hydroxyl, sulfate, phosphate and amino groups present on the cell surface (Abbas et al. 2014; Dhankhar, Hooda 2011).

Several fungal biosorbents such as Phanerochaete chrysosporium (Marandi et al. 2010), Penicillium chrysogenum (Tan, Cheng 2003), Aspergillus niger (Vale et al. 2016) and Rhizopus arrhizus (Preetha, Viruthagiri 2005) have been used in $\mathrm{Zn}^{2+}$ removal from wastewater. Humicola sp. fungus occurs in the Mae Toa creek sediments from zinc mine area, Tak province, Thailand (Netpae et al. 2015). Study showed that Humicola sp. is an excellent adsorbent for metal ions in aqueous solutions (Netpae et al. 2014). There is no information on the use of Humicola phialophoroides for the biosorption of zinc. In this study, adsorption ability by viable, non-viable and two types of pretreated $H$. phialophoroides biomass were investigated for removal of $\mathrm{Zn}^{2+}$ from aqueous solution under experimental conditions.

\section{Materials and methods}

\section{Microorganisms}

The Humicola sp. was isolated from Mae Tao creek sediments from the zinc ore area in Mae Sot District, Tak Province, Thailand. The fungus was identified at the species level as follows. Fungal DNA was extracted with a NucleoSpin ${ }^{\oplus}$ Extract Kit (Macherey-Nagel, Germany). The complete internal transcribed spacer (ITS) region of rDNA was amplified with the primers ITS 1 to 4 and sequenced. The resulting 873-bp sequence was deposited in GenBank (GU988752.1). The sequence showed 99\% similarity 
Table 1. Linear isotherm models forms used in this study. C, the equilibrium concentration $\left(\mathrm{L} \mathrm{g}^{-1}\right)$; B, a constant related heat of sorption $\left(\mathrm{J} \mathrm{mol}^{-1}\right)$ by B = RT / bT; q, the amount of metal ions adsorbed $\left(\mathrm{mg} \mathrm{g}^{-1}\right)$; bT, the Temkin isotherm constant; qm, the maximum monolayer coverage $\left(\mathrm{mg} \mathrm{g}^{-1}\right)$; $\mathrm{R}$, the universal gas constant $\left(8.314 \mathrm{~J} \mathrm{~mol}^{-1} \mathrm{~K}^{-1}\right)$; KL, the Langmuir constant $\left(\mathrm{L} \mathrm{mg}^{-1}\right)$; $\mathrm{T}$, the temperature at $298 \mathrm{~K}$; KF, the Freundlich constant related to the adsorption capacity; $\mathcal{E}$, RTln $[1+(1 / \mathrm{C})]$; A, the Temkin isotherm equilibrium binding constant $\left(\mathrm{L} \mathrm{g}^{-1}\right)$

$\begin{array}{lccc}\text { Isotherm model } & \text { x-axis } & \text {-axis } & \text { Linear form } \\ \text { Langmuir } & 1 / \mathrm{q} & 1 / \mathrm{C} & 1 / \mathrm{q}=\left(1 / \mathrm{q}_{\mathrm{m}} \mathrm{K}_{\mathrm{L}}\right)(1 / \mathrm{C})+1 / \mathrm{qm} \\ \text { Freundlich } & \log \mathrm{q} & \log \mathrm{C} & \log \mathrm{q}=1 / \mathrm{n} \log \mathrm{C}+\log \mathrm{KF} \\ \text { Temkin } & \mathrm{Q} & \ln \mathrm{q} & \mathrm{q}=\mathrm{B} \ln \mathrm{A}+\mathrm{B} \ln \mathrm{C} \\ \text { Dubinin-Radushkevich } & \mathrm{Lnq} & \varepsilon^{2} & \operatorname{lnq}=\ln \mathrm{q}_{\mathrm{m}}-\mathrm{k} \varepsilon^{2}\end{array}$

with sequences of $H$. phialophoroides. Fungal spores were obtained from a 5 days old culture grown on Potato Dextrose Agar (PDA) at $30 \pm 2{ }^{\circ} \mathrm{C}$. Colonies grown on PDA were white with abundant aerial hyphae. The colony colour was light yellow initially and later became light brown with irradiation. The spores were collected in $0.01 \%$ Tween- 80 solution.

\section{Reagents}

Zinc nitrate hexahydrate $\left[\mathrm{Zn}\left(\mathrm{NO}_{3}\right)_{2} \quad 6 \mathrm{H}_{2} \mathrm{O}\right]$ was used to prepare $1000 \mathrm{mg} \mathrm{L}^{-1}$ standard stock solution of $\mathrm{Zn}^{2+}$ ion solution. All chemicals used in this research were of analytical grade, and solutions were prepared using deionised water.

\section{Zinc tolerance test experiment}

H. phialophoroides dry biomass was weighed after 3 days incubation on a rotary shake flask at $30 \pm 2^{\circ} \mathrm{C}$ and $150 \mathrm{rpm}$ in the PDB broth with zinc concentration 10,25, 50 and 100 $\mathrm{mg} \mathrm{L}^{-1}$, as compared to that without zinc.

\section{Biomass preparation}

Biomass of $H$. phialophoroides was cultivated in Potato Dextrose Broth (PDB), using the shake flask method. Spore suspension $\left(10^{8}\right.$ spores) were cultivated in a $250 \mathrm{~mL}$ Erlenmeyer flask with $50 \mathrm{ml} \mathrm{PDB}$ at $30 \pm 2{ }^{\circ} \mathrm{C}$ with a shaker at a speed of $150 \mathrm{rpm}$ for 3 days. The viable biomass was harvested by filtration and subjected to successive washings with deionised water. Then non-viable biomass was prepared by autoclaving the viable biomass at $121^{\circ} \mathrm{C}$ for 20 min and then harvested by filtering through a membrane filter, it was then dried at $80^{\circ} \mathrm{C}$ in an oven for $12 \mathrm{~h}$. The pretreated biomass was suspended in $10 \% \mathrm{HNO}_{3}$ and $10 \%$ $\mathrm{NaOH}$ solutions for $30 \mathrm{~min}$ at $30 \pm 2{ }^{\circ} \mathrm{C}$. Subsequently, the biomasses were collected and washed with deionized water until the $\mathrm{pH}$ of the wash solution was in near neutral range ( $\mathrm{pH} 7$ ). The pretreated biomass was killed in an autoclave and then harvested by filtering through a membrane filter and then dried at $80{ }^{\circ} \mathrm{C}$ in an oven for $12 \mathrm{~h}$. Finally, nonviable biomass and pretreated biomass were then ground, using a blender to break cell aggregates into smaller fragments. The biomass was then passed through $100 \mu \mathrm{m}$ mesh sieves of to obtain particle sizes of less than 0.5 to 1.0 $\mathrm{mm}$ diameter.

\section{Batch isotherm experiments}

The equilibrium sorption of the $\mathrm{Zn}^{2+}$ ions onto biomass was carried out by contacting $0.1 \mathrm{~g}$ of the substrate with $50 \mathrm{~mL}$ of different concentrations from 0 to $150 \mathrm{mg} \mathrm{L}^{-1}$ for 120 min on the shaker at a speed of $150 \mathrm{rpm}$. The amount of metal bound by the biosorbent was calculated as:

$$
q=C i-C f \times V \times W,
$$

where $q$ is the metal uptake ( $\mathrm{mg} \mathrm{Zn} \mathrm{g}^{-1}$ dry mass), and $\mathrm{Ci}$ and $C f$ are the initial and final $\mathrm{Zn}^{2+}$ concentrations in the supernatant, respectively $\left(\mathrm{mg} \mathrm{L}^{-1}\right), V$ is the volume of the zinc concentration $(\mathrm{mL})$, and $W$ is the dry mass of the biomass added (g). Linear forms of the isotherms models have been widely adopted to determine the isotherm parameters or the most fitted model for the adsorption system due to the mathematical simplicity. The sorption isotherms of $\mathrm{Zn}^{2+}$ were studied by fitting the obtained data to linear forms of the Langmuir (Langmuir 1916), Freundlich (Freundlich 1906), Temkin (Temkin, Pyzhev 1940) and Dubinin-Radushkevich (Dubinin, Radushkevich 1947) isotherm models (Table 1). The best fit model was selected based on the determination coefficient $\left(R^{2}\right)$.

\section{Effect of temperature, $\mathrm{pH}$ and contact time on $\mathrm{Zn}$ removal by fungus}

In order to evaluate the effect of temperature, $\mathrm{pH}$ and contact time on the $\mathrm{Zn}^{2+}$ uptake, the experiment was conducted in the same manner, except the temperature of zinc solution was changed to $30,40,50,60$ and $70{ }^{\circ} \mathrm{C}$. The $\mathrm{pH}$ of the solution was prepared to be in the range between 3.0 and 8.0 before mixing biomass. The $\mathrm{pH}$ was adjusted to

Table 2. Dry weight of mycelium of $H$. phialophoroides in PDB with and without $\mathrm{Zn}^{2+}$ after 3 days of incubation. Means followed by the same letter are not significantly different $(p<0.05)$

$\begin{array}{|lcc|}\begin{array}{l}\text { Zinc concentration } \\ \left(\mathbf{m g ~ L}^{-1}\right)\end{array} & \begin{array}{c}\text { Mycelium dry mass of Humicola } \\ \text { phialophoroides }\end{array} \\$\cline { 2 - 3 } & $\left.(\mathbf{g}) & (\%)\end{array}\right)$


Table 3. $\mathrm{Zn}^{2+}$ uptake in biiomass of $H$. phialophoroides. Means followed by the same letter are not significantly different $(p<0.05)$

\begin{tabular}{lcccc}
$\begin{array}{l}\text { Zinc } \\
\text { concentration } \\
\left(\mathbf{m g ~ L}^{-1}\right)\end{array}$ & Viable biomass & Non-viable biomass & $\mathrm{HNO}_{3}$ pretreated biomass & NaOH pretreated biomass \\
0 & & & & \\
\hline 1 & $0.00 \pm 0.00 \mathrm{a}$ & $0.00 \pm 0.00 \mathrm{a}$ & $0.00 \pm 0.00 \mathrm{a}$ & $0.00 \pm 0.00 \mathrm{a}$ \\
\hline 5 & $0.25 \pm 0.01 \mathrm{~b}$ & $0.23 \pm 0.01 \mathrm{~b}$ & $0.27 \pm 0.01 \mathrm{~b}$ & $0.31 \pm 0.05 \mathrm{~b}$ \\
\hline 10 & $1.21 \pm 0.012 \mathrm{c}$ & $1.17 \pm 0.012 \mathrm{c}$ & $1.30 \pm 0.032 \mathrm{c}$ & $1.51 \pm 0.65 \mathrm{~d}$ \\
\hline 25 & $1.69 \pm 0.01 \mathrm{~d}$ & $1.68 \pm 0.01 \mathrm{~d}$ & $1.90 \pm 0.01 \mathrm{e}$ & $2.12 \pm 0.02 \mathrm{f}$ \\
\hline 50 & $2.17 \pm 0.01 \mathrm{f}$ & $2.14 \pm 0.03 \mathrm{f}$ & $2.42 \pm 0.02 \mathrm{~g}$ & $2.74 \pm 0.01 \mathrm{~h}$ \\
\hline 100 & $5.12 \pm 0.12 \mathrm{j}$ & $5.13 \pm 0.10 \mathrm{j}$ & $4.81 \pm 0.16 \mathrm{i}$ & $6.42 \pm 0.08 \mathrm{no}$ \\
150 & $5.77 \pm 0.07 \mathrm{~m}$ & $5.34 \pm 0.18 \mathrm{k}$ & $5.49 \pm 0.13 \mathrm{kl}$ & $6.35 \pm 0.33 \mathrm{n}$ \\
\hline
\end{tabular}

the required value with $0.1 \mathrm{M} \mathrm{NaOH}$ or $0.1 \mathrm{M} \mathrm{HNO}_{3}$. The period of contact time was studied up to 180 min by using the procedure described earlier, and samples were collected every $30 \mathrm{~min}$.

\section{Zn desorption experiments}

The $0.1 \mathrm{M} \mathrm{HNO}_{3}$ solution was used to elute $\mathrm{Zn}^{2+}$ from the biomass. Following the $\mathrm{Zn}^{2+}$ sorption experiments, the $\mathrm{Zn}$ loaded biomass was prepared by centrifugation, washed and returned to $25 \mathrm{~mL}$ of the effluent $0.1 \mathrm{M} \mathrm{HNO}_{3}$ for 30 min on a rotary shaker $(125 \mathrm{rpm})$. Zinc concentration was determined after separating the biomass from eluting agent by filtration.

\section{Atomic absorption analysis}

The concentration of $\mathrm{Zn}^{2+}$ was measured using an atomic absorption spectrophotometer (Perkin Elmer model PinAAcle $900 \mathrm{~T}$ ) by the flameless method of graphite system.

\section{Statistical analysis}

All the experiments were run in triplicate. Mean values were used in analysis of data by using the analysis of variance (one-way ANOVA) and Post Hoc Duncan test $(p<0.05)$.

\section{Results and discussion}

\section{Minimum inhibitory concentrations}

The dry biomass was not significantly different between the control and the treatment at $\mathrm{Zn}^{2+}$ concentrations from 0 to $50 \mathrm{mg} \mathrm{L}^{-1}$ (Table 2). In the $100 \mathrm{mg} \mathrm{Zn}^{2+}$ treatment, mycelial dry weight of $H$. phialophoroides was significantly lover. This indicates that the more tolerant species have mechanisms and physiological adaptation to resist higher $\mathrm{Zn}^{2+}$ concentrations and to avoid its toxic effect response to the concentrations of the $\mathrm{Zn}^{2+}$ ions, which makes it an attractive potential candidate for further investigation regarding its ability to remove $\mathrm{Zn}^{2+}$ from contaminated water.

Table 4. Isotherm parameter models for $\mathrm{Zn}^{2+}$ adsorption onto different types of $H$. phialophoroides biomass

\begin{tabular}{|c|c|c|c|c|}
\hline Isotherms & Viable biomass & Non-viable biomass & $\begin{array}{c}\mathrm{HNO}_{3} \text { pretreated } \\
\text { biomass }\end{array}$ & $\begin{array}{c}\mathrm{NaOH} \text { pretreated } \\
\text { biomass }\end{array}$ \\
\hline \multicolumn{5}{|l|}{ Langmuir } \\
\hline $\mathrm{q}_{\mathrm{m}}\left(\mathrm{mg} \mathrm{Zn} \mathrm{g}^{-1} \mathrm{DM}\right)$ & 5.495 & 5.942 & 5.695 & 6.835 \\
\hline $\mathrm{K}_{\mathrm{L}}\left(1 \mathrm{mg}^{-1}\right)$ & 0.529 & 0.548 & 0.475 & 0.351 \\
\hline$R^{2}$ & 0.9961 & 0.9962 & 0.9972 & 0.9964 \\
\hline \multicolumn{5}{|l|}{ Freundlich } \\
\hline $\mathrm{K}_{\mathrm{F}}\left(\mathrm{mg} \mathrm{g}^{-1}\right)\left(\mathrm{l} \mathrm{mg}^{-1}\right)^{1 / \mathrm{n}}$ & 0.401 & 0.379 & 0.450 & 0.508 \\
\hline $\mathrm{N}$ & 1.691 & 1.672 & 1.785 & 1.742 \\
\hline$R^{2}$ & 0.9464 & 0.9388 & 0.9392 & 0.932 \\
\hline \multicolumn{5}{|l|}{ Temkin } \\
\hline $\mathrm{A}\left(\mathrm{lg}^{-1}\right)$ & 1.162 & 1.152 & 1.007 & 1.039 \\
\hline B & 1.180 & 1.135 & 1.103 & 1.336 \\
\hline$R^{2}$ & 0.8836 & 0.8853 & 0.9207 & 0.8824 \\
\hline \multicolumn{5}{|l|}{ Dubinin-Radushkevich } \\
\hline $\mathrm{q}_{\mathrm{m}}\left(\mathrm{mg} \mathrm{Zn} \mathrm{g}^{-1} \mathrm{DM}\right)$ & 3.187 & 3.106 & 3.257 & 3.843 \\
\hline $\mathrm{k}\left(\mathrm{mol}^{2} \mathrm{~kJ}^{-2}\right)$ & 0.0006 & 0.0006 & 0.0006 & 0.0006 \\
\hline$R^{2}$ & 0.7385 & 0.7538 & 0.7771 & 0.7618 \\
\hline
\end{tabular}



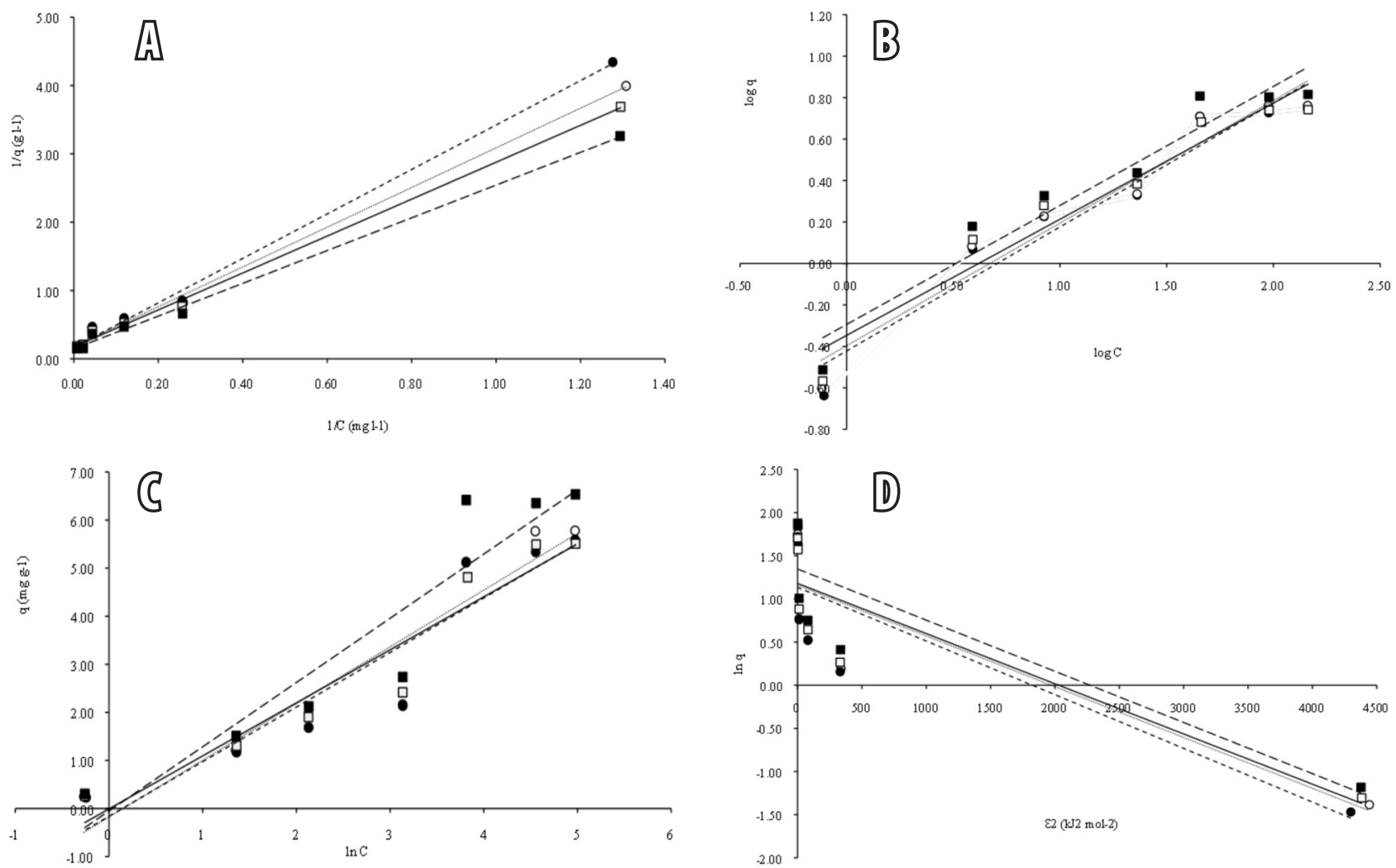

Fig. 1. Langmuir (A), Freundlich (B), Temkin (C) and Dubinin-Radushkevich (D) isotherms of $\mathrm{Zn}^{2+}$ removal by different types of $H$. phialophoroides biomass: viable biomass $(\mathrm{O})$, non-viable biomass

, $\mathrm{HNO} 3$ pretreated biomass $(\square)$ and $\mathrm{NaOH}$ pretreated biomass (ם).

\section{$\mathrm{Zn}^{2+}$ uptake by H. phialophoroides biomass}

The results related to $\mathrm{Zn}^{2+}$ biosorption by viable, non-viable and two types of pretreated biomasses are presented in Table 3. The $\mathrm{NaOH}$ pretreated $H$. phialophoroides had the highest biosorbent activity for $\mathrm{Zn}^{2+}$ among the biomasses studied. An increase in biosorption of $\mathrm{Zn}^{2+}$ as a result of pretreatment by $\mathrm{NaOH}$ could be due to exposure of active metal binding sites embedded in the cell wall or chemical modifications of the cell wall components (Javaid et al. 2011).

The graphs of all adsorption isotherm models are shown in Fig. 1; the correlation coefficients and the intercept values are shown in Table 4, the highest $R^{2}$ was obtained by fitting experimental data into the Langmuir isotherm model, as compared with the Freundlich, Temkin and DubininRadushkevic isotherm models. The Langmuir isotherm model assumes monolayer adsorption in which adsorbates are adsorbed to a finite number of definite localised sites that are identical and equivalent with no lateral interaction. This isotherm model reflects the homogeneous adsorption mechanism where each molecule owns its enthalpy and activation energy at the same time. This model does not permit transmigration of the adsorbate in the plane of the surface (Perez Marín et al. 2007). The values of maximum monolayer adsorption capacity of $H$. phialophoroides biomass were 5.495, 5.942, 5.695 and $6.835 \mathrm{mg} \mathrm{Zn} \mathrm{g}^{-1}$ dry wt. for viable biomass, non-viable biomass, $\mathrm{HNO}_{3}$ treated biomass and $\mathrm{NaOH}$ treated biomass, respectively. These values are higher than for many fungal biomasses such as, Aspergillus niger (Vale et al. 2016), Penicillium chrysogenum (Tan, Cheng 2003), but lower than for Rhizopus arrhizus (Kapoor, Viraraghavan 1995) and Streptoverticillium cinnamoneum (Puranik, Paknikar 1997).

Table 5. Desorption of $\mathrm{Zn}^{2+}$ from different types of biomass of $H$. phialophoroides

\begin{tabular}{|c|c|c|c|}
\hline \multirow[t]{2}{*}{ Biomass } & \multicolumn{2}{|c|}{ Zinc uptake (mg Zn $\mathrm{g}^{-1} \mathrm{DM}$} & \multirow[t]{2}{*}{ Removal efficiency (\%) } \\
\hline & Before desorption & After desorption & \\
\hline Viable biomass & $5.29 \pm 0.08$ & $4.68 \pm 0.63$ & 88.47 \\
\hline Non-viable biomass & $5.15 \pm 0.59$ & $4.84 \pm 0.34$ & 93.98 \\
\hline $\mathrm{HNO}_{3}$ pretreated biomass & $4.86 \pm 0.07$ & $4.49 \pm 0.66$ & 92.39 \\
\hline $\mathrm{NaOH}$ pretreated biomass & $6.63 \pm 0.65$ & $6.12 \pm 0.34$ & 92.31 \\
\hline
\end{tabular}



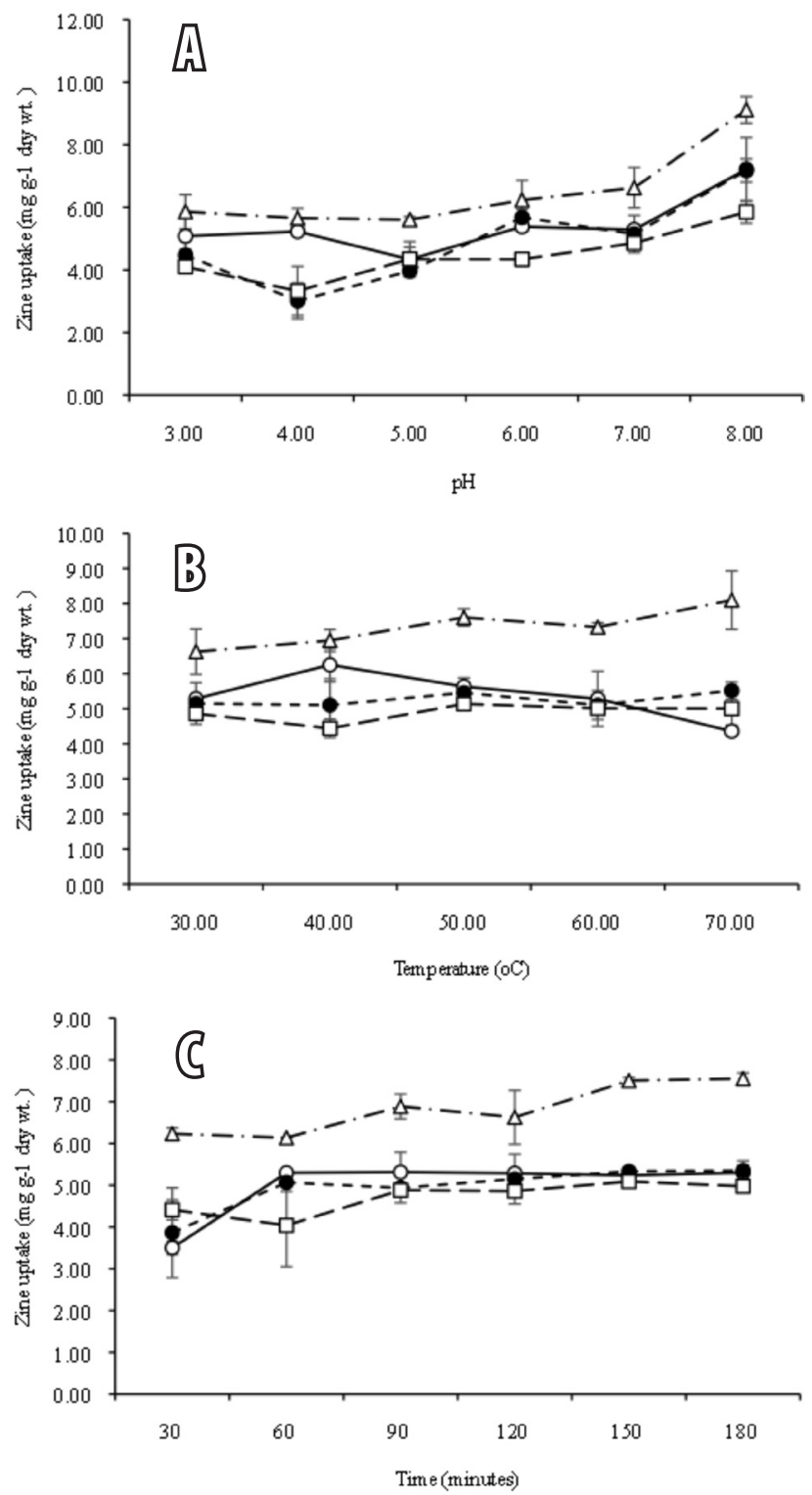

Fig. 2. Effect of $\mathrm{pH}(\mathrm{A})$, temperature (B) and contact time (C) on $\mathrm{Zn}^{2+}$ removal by $H$. phialophoroides biomass: viable biomass $(\bigcirc)$, non-viable biomass $(\bullet), \mathrm{HNO}_{3}$ pretreated biomass $(\square)$ and $\mathrm{NaOH}$ pretreated biomass $(\Delta)$.

\section{Effect of $\mathrm{pH}$ on biosorption}

The effect of $\mathrm{pH}$ on $\mathrm{Zn}$ uptake was measured in the $\mathrm{pH}$ range from 3 to 8 (Fig. 2A). The graph shows that adsorption was low at $\mathrm{pH} 3$ to 6 , while the $\mathrm{Zn}^{2+}$ was well adsorbed in the high $\mathrm{pH}$ range from 7 to $8(p<0.05)$. The $\mathrm{NaOH}$ treated biomass showed highest detoxification of $\mathrm{Zn}^{2+}$ at $\mathrm{pH} 8$, with a value of $9.11 \pm 0.04 \mathrm{mg} \mathrm{g}^{-1}$ dry mass.

Many studies have shown that $\mathrm{pH}$ is an important factor affecting biosorption of $\mathrm{Zn}^{2+}$ (Vale et al. 2016; Vaishnav et al. 2012; Javaid et al. 2011). The solution $\mathrm{pH}$ influences the adsorbent surface charge. Zinc ion adsorption is affected by the initial solution $\mathrm{pH}$ and the change in $\mathrm{pH}$ influences the adsorption process. The biosorption capacity of biomass is low at acid conditions, because large quantities of proton compete with the metal cations for the adsorption sites. As the $\mathrm{pH}$ of the metal solution increases, the number of protons dissociated from functional groups of carboxylate on the cell wall increases and thus more negative groups for complexation of metal cations are provided (Kapoor et al. 1999).

\section{Effect of temperature on biosorption}

The effect of temperature on $\mathrm{Zn}^{2+}$ removal from aqueous solution by $H$. phialophoroides biomass was measured in the temperature range between 30 to $70{ }^{\circ} \mathrm{C}$ at $\mathrm{pH}$. The $\mathrm{Zn}^{2+}$ removal in viable biomass was lower at $50^{\circ} \mathrm{C}$ (Fig. 2B), while the $\mathrm{Zn}^{2+}$ biosorption by non-viable biomass and two pretreated types of biomass were not significantly affected in the temperature range of 30 to $70^{\circ} \mathrm{C}$. The highest value of $\mathrm{Zn}^{2+}$ removal $\left(8.10 \pm 0.83 \mathrm{mg} \mathrm{g}^{-1}\right.$ dry mass $)$ occurred at $80^{\circ} \mathrm{C}$ in $\mathrm{NaOH}$ treated biomass. Previous studies related to metal sorption by fungi indicated that the effect of temperature on biosorption depended on the metal biosorbent systems (Marandi et al. 2010; Netpae et al. 2014).

\section{Effect of contact time on biosorption}

The uptake of $\mathrm{Zn}^{2+}$ by the H. phialophoroides biomasses was examined at different time intervals and the results are shown in Fig. 2C. Studies have shown that biosorption efficiency of $\mathrm{Zn}^{2+}$ increases with increased contact time. Viable biomass, non-viable biomass and $\mathrm{HNO}_{3}$ treated biomass could also remove $\mathrm{Zn}^{2+}$ in solution and reached the equilibrium within $90 \mathrm{~min}$, while the rate of $\mathrm{Zn}^{2+}$ adsorption by $\mathrm{NaOH}$ treated biomass was increased with contact time up to $150 \mathrm{~min}$ and then remained stable until $180 \mathrm{~min}$. The initial faster uptake might be due to the availability of abundant metal species and empty metal binding sites of microbes. Slower phase might be due to saturation of metal binding site (Mathivanan, Rajaram 2014).

\section{Desorption}

Desorption of biosorbed $\mathrm{Zn}^{2+}$ was achieved by elution with $0.1 \mathrm{M} \mathrm{HNO}_{3}$ (Table 5). The $\mathrm{Zn}^{2+}$ removal was decreased by about $88.47,93.98,92.39$, and $92.31 \%$ for viable biomass, non-viable biomass, $\mathrm{HNO}_{3}$ treated biomass and $\mathrm{NaOH}$ treated biomass, respectively. The decrease in $\mathrm{Zn}^{2+}$ uptake by $0.1 \mathrm{M} \mathrm{HNO}_{3}$ desorbent might be due to the increase of the concentrations of competing $\mathrm{H}_{3} \mathrm{O}^{+}$. It is also possible that the physical structure of the biomass becomes damaged by $\mathrm{HNO}_{3}$ (Sun et al. 2010).

\section{Conclusions}

This study demonstrated that $H$. phialophoroides possesses good capacity for $\mathrm{Zn}^{2+}$ biosorption from aqueous solution and industrial wastewater. The adsorption equilibrium of $\mathrm{Zn}^{2+}$ sorption at low concentration can be described by the Langmuir isotherm model. The values of maximum monolayer adsorption capacity of $H$. phialophoroides 
biomasses were 5.495, 5.942, 5.695 and $6.835 \mathrm{mg} \mathrm{Zn} \mathrm{g}^{-1}$ dry mass for viable biomass, non-viable biomass, $\mathrm{HNO}_{3}$ treated biomass and $\mathrm{NaOH}$ treated biomass, respectively. Maximum $\mathrm{Zn}^{2+}$ biosorption of biomass pretreated with $\mathrm{NaOH}$ occurred at $\mathrm{pH}$ more than 8 after $150 \mathrm{~min}$. Moreover, the $\mathrm{Zn}^{2+}$ was well adsorped by biomass at high temperature $\left(70{ }^{\circ} \mathrm{C}\right)$. Desorption experiments indicated that the desorption efficiency with $0.1 \mathrm{M} \mathrm{HNO}_{3}$ solution reached $92.31 \%$.

\section{Acknowledgements}

Financial support from Nakhon Sawan Rajabhat University, Thailand is gratefully acknowledged.

\section{References}

Abbas S.H., Ismail I.M., Mostafa T.M., Sulaymon A.H. 2014. Biosorption of heavy metals: A review. J Chem Sci Tech. 3: 74-102.

Dhankhar, R., Hooda, A. 2011. Fungal biosorption - an alternative to meet the challenges of heavy metal pollution in aqueous solutions. Environ. Technol. 32: 467-491.

Dubinin M.M., Radushkevich L.V. 1947. The equation of the characteristic curve of the activated charcoal. Proc. Acad. Sci. USSR Phys. Chem. Sect. 55: 331-337.

Freundlich H.M.F. 1906. Over the adsorption in solution. J. Phys. Chem. 57: 385-471.

Hosford W.F. 2013. Elementary Materials Science. ASM International Materials Park Ohio.

Javaid A., Bajwa R., Manzoor T. 2011.Biosorption of heavy metal by pretreated biomass of Aspergillus niger. Pak. J. Bot. 43: 419425.

Kapoor A., Viraraghavan T. 1995. Fungal biosorption - an alternative treatment option for heavy metal bearing wastewater: A review. Bioresour. Technol. 53: 195-206.

Kapoor A., Viraraghavan T., Cullimore D.R. 1999. Removal of heavy metals using the fungus Aspergillus niger. Bioresour. Technol. 70: 95-104.

Langmuir, I. 1916. The constitution and fundamental properties of solids and liquids. J. Am. Chem. Soc. 38: 2221-2295.

Marandi R., Ardejani F.D., Afshar H.A. 2010. Biosorption of lead (II) and zinc (II) ions by pre-treated biomass of Phanerochaete chrysosporium. Int. J. Mining Environ. Iss. 1: 9-16.

Mathivanan K., Rajaram R. 2014. Tolerance and biosorption of cadmium (II) ions by highly cadmium resistant bacteria isolate from industrially polluted estuatine environment. Indian J. Mar. Sci. 43: 580-588.

Netpae T., Suckley S., Phalaraksh C. 2015. Cadmium tolerance fungi isolated from polluted sites in the Mae Tao creek, Thailand. Adv. Stud. Biol. 7: 29-37.

Netpae T., Suckley S., Phalaraksh C . 2014. Biosorption of $\mathrm{Cd}^{2+}$ from aqueous solutions by tolerant fungus Humicola sp. Adv. Environ Biol. 8: 308-312.

Perez Marín A.B., Meseguer Zapata V., Ortuno J.F., Aguilar M., Saez J., Llorens M. 2007. Removal of cadmium from aqueous solutions by adsorption onto orange waste. J. Hazard. Mater. 139: 122-131.

Preetha B., Viruthagiri T. 2005. Biosorption of zinc (II) by Rhizopus arrhizus: equilibrium and kinetic modelling. Afr. J. Biotechnol. 4: 506-508.

Puranik P., Paknikar K.M. 1997. Biosorption of lead and zinc from solutions using Streptoverticillium cinnamoneum waste biomass. J. Biotechnol. 55: 113-124.

Sun Y.M., Horng C.Y., Chang F.L., Cheng L.C., Tian W.X. 2010. Biosorption of lead, mercury, and cadmium ions by Aspergillus terreus immobilized in a natural matrix. Polish J. Microbiol. 59: 37-44.

Tan T., Cheng P. 2003. Biosorption of metal ions with Penicillium chrysogenum. Appl. Biochem. Biotechnol. 104: 119-128.

Temkin M.I., Pyzhev V. 1940. Kinetics of ammonia synthesis on promoted iron catalyst. Acta Physiochim. URSS 12: 217-222.

The National Mining Association. 2014. U.S. Mines to market. SNL Metals \& Mining. London, pp. 34-36.

US Geological Survey. 2014. Mineral Commodity Summaries 2014. Virginia: US Geological Survey. pp. 186-187.

Vaishnav V., Kailash D., Suresh C., Madan L. 2012. Adsorption studies of $\mathrm{Zn}$ (II) ions from wastewater using Calotropis procera as an adsorbent. Res. J. Recent. Sci. 1: 160-165.

Vale M.S., Nascimento R.F. Leitao R.C., Santaella S.T. 2016. Cr and $\mathrm{Zn}$ biosorption by Aspergillus niger. Environ. Earth Sci. 75: 461-'466.

World Health Organization. 2003. Zinc in drinking-water. WHO, Geneva, pp.1-5.

Zabochnicka-Świątek M., Krzywonos M. 2014. Potentials of biosorption and bioaccumulation processes for heavy metal removal. Polish J. Environ. Stud. 23: 551-561. 